\title{
The Study on the Reducibility of Itakpe Iron Ore Lumps
}

ISSN: 2576-8840

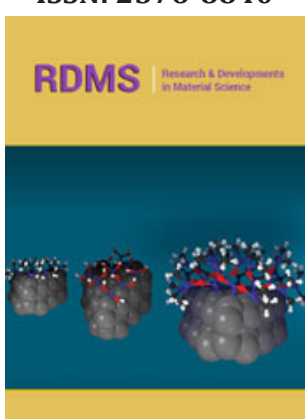

*Corresponding author: Ocheri C, Department of Metallurgical and Materials Engineering, University of Nigeria, Nsukka

Submission: 笽 May 28, 2020

Published: 眥June 19, 2020

Volume 13 - Issue 4

How to cite this article: Ocheri $\mathrm{C}$, Njoku RE, Urama NA, Adams S Mohammed, Mbah CN, Chikezie WO, Ezeanyanwu J. The Study on the Reducibility of Itakpe Iron Ore Lumps Res Dev Material Sci. 13(4). RDMS.000819. 2020 DOI: $10.31031 /$ RDMS.2020.13.000819

Copyright@ Ocheri C, This article is distributed under the terms of the Creative Commons Attribution 4.0 International License, which permits unrestricted use and redistribution provided that the original author and source are credited.

\author{
Ocheri $\mathrm{C}^{1 *}$, Njoku $\mathrm{RE}^{2}$, Urama $\mathrm{NA}^{3}$, Adams S Mohammed ${ }^{3}, \mathrm{Mbah}_{\mathrm{CN}}{ }^{3}, \mathrm{Chikezie}$ \\ WO $^{4}$ and Ezeanyanwu J ${ }^{4}$ \\ 1,2,3 Department of Metallurgical and Materials Engineering, University of Nigeria, Nigeria \\ ${ }^{3,4}$ Department of Metallurgical and Materials Engineering, Enugu State University of Science \\ and Technology, Nigeria
}

\begin{abstract}
The study on the reducibility on the Itakpe iron ore lumps were carried out. The chemical compositions, structural analysis and morphological structures of the ores were examined. Some analytical instruments and equipment were used to determine the Thermogravimetry (TG), the Differential Thermal Analyzer (DTA), the X-Ray Fluorescence (XRF) and X-Ray Diff action (XRD). Optical Microscopy and Scanning Electron Microscopy (SEM) with Energy Dispersive Spectroscopy (EDS) were also used for further analyses.The reducibility study was performed in the laboratories of the Department of Metallurgical and Materials Engineering, University of Nigeria, Nsukka, Nigeria. A muffle furnace with model number LABE 1210, Divine international. The heating capacity of $1500{ }^{\circ} \mathrm{C}$ as the heating device was used for the experiments. The samples were heated to temperature range from $800^{\circ} \mathrm{C}$ to $1000^{\circ} \mathrm{C}$ with temperature interval of $40^{\circ} \mathrm{C}$. The duration allowed for each of the experiments ranged from 20 minutes to 120 minutes and also allowed interval time of 20 minutes. The iron ore lumps were taken inside six stainless steel containers with diameter $0.675 \mathrm{~cm} \times 0.594 \mathrm{~cm}$ inside diameter with the mouths tightly closed with air tight covers for gas escape, the metallurgical coking coal obtained from the Ajaokuta Steel Company Limited was used as a reducing agents. The highest reduction value of Itakpe iron ore lump was obtained at $74.3 \%$ with corresponding temperature at $1000{ }^{\circ} \mathrm{C}$ at time rate of 120 minutess. The (SEM) and (EDS) were used to determine the iron (Fe) content after the reducibility tests were performed. Some recommendations and contributions from the research work was stated to assist the would - be researchers in this field of study.
\end{abstract}

Keywords: Study; Reducibility; Itakpe; Iron ore; Lumps

\section{Introduction}

The Itakpe iron ore deposit is located northeast of Okene in the eastern part of Kogi state. This ore deposit is mostly used for research works in Nigeria; this development is due to its usefulness for the operation of the Blast Furnace at an integrated steel plant in Nigeria located at the Ajaokuta Steel Company Limited. Subsequently, the ores are used as feeds at the Delta Steel Company, Aladja, Delta state (Direct Reduced Iron).

The plateau is made of scattered hills, that are made of Precambrian gneisses and granites that are surrounded with about $200 \mathrm{~m}$ to $300 \mathrm{~m}$. The ore deposit is estimated to have a reserve of over 300 million tones. The verified reserve has been put to be around 200 million tones [1].

\section{Reducibility}

This is known as the velocity of iron oxide transformation to metal by the effect of reduction gas, it is also known as time needed for a complete iron oxide reduction. The value of the reduction rate is the metallic charge weight loss per a time unit. The weight loss caused by the charge oxygen transformation into gas.

It has a lot of influence on the blast furnace operation that is very essential it can serve as fuel consumption for the determination selection and completeness of utilizing of the lumpiness. The reducibility test method is one of the most important methods to determine the behaviour of natural and processed iron ores. Iron ores are upgraded to higher iron ore content through beneficiation processes. 


\section{Research Methodology}

\section{Materials}

Itakpe iron ore: The topography of the region is a plateau rising gently to the north-east of Okene in the eastern, part of Kogi State, down to the river Niger. The plateau is bestrewn with scattered hills, which are made of Precambrian gneisses, and granites that overlook the surrounding by about $200 \mathrm{~m}$ to $300 \mathrm{~m}$ [1]. The Itakpe iron ore specimen is known to be a compacted, crystalline - like banded iron ore, which has various colours like dark grey, brown and black. The Itakpe iron ore slightly magnetic in nature.

Table 1: Shows the chemical compositions of Itakpe Iron Ore using XRF Method.

\begin{tabular}{|c|c|c|}
\hline Component & Unit & Result \\
\hline $\mathrm{Na}_{2} \mathrm{O}$ & mass $\%$ & 0.35 \\
\hline $\mathrm{MgO}$ & mass $\%$ & 0.39 \\
\hline $\mathrm{Al}_{2} \mathrm{O}_{3}$ & mass $\%$ & 12.2 \\
\hline $\mathrm{SiO}_{2}$ & mass $\%$ & 20.5 \\
\hline $\mathrm{P}_{2} \mathrm{O}_{5}$ & mass $\%$ & 1.56 \\
\hline $\mathrm{SO}_{3}$ & mass $\%$ & 0.14 \\
\hline $\mathrm{K}_{2} \mathrm{O}$ & mass $\%$ & 0.61 \\
\hline $\mathrm{CaO}$ & mass $\%$ & 0.11 \\
\hline $\mathrm{TiO}_{2}$ & mass $\%$ & 1.4 \\
\hline $\mathrm{V}_{2} \mathrm{O}_{5}$ & mass $\%$ & 0.08 \\
\hline $\mathrm{Cr}_{2} \mathrm{O}_{3}$ & mass $\%$ & 0.06 \\
\hline $\mathrm{MnO}$ & mass $\%$ & 0.16 \\
\hline $\mathrm{Fe}_{2} \mathrm{O}_{3}$ & mass $\%$ & 52.5 \\
\hline $\mathrm{NiO}$ & mass $\%$ & 0.02 \\
\hline $\mathrm{CuO}$ & mass $\%$ & 0.03 \\
\hline $\mathrm{ZnO}$ & mass $\%$ & 0.02 \\
\hline $\mathrm{Rb}_{2} \mathrm{O}$ & mass $\%$ & 0.01 \\
\hline $\mathrm{SrO}$ & mass $\%$ & 0.01 \\
\hline $\mathrm{ZrO}_{2}$ & mass $\%$ & 0.05 \\
\hline $\mathrm{BaO}$ & mass $\%$ & 0.2 \\
\hline
\end{tabular}

Chemical analysis of Itakpe: Table 1 shows the analytical results of the Itakpe iron ore chemical compositions. This was determined with the use of the X- Ray Fluorescence (XRF) methods. The experiments were performed at the laboratory of the Tshwane University of Technology, South Africa [2].

X-Ray Diffraction (XRD) on Itakpe iron ore:

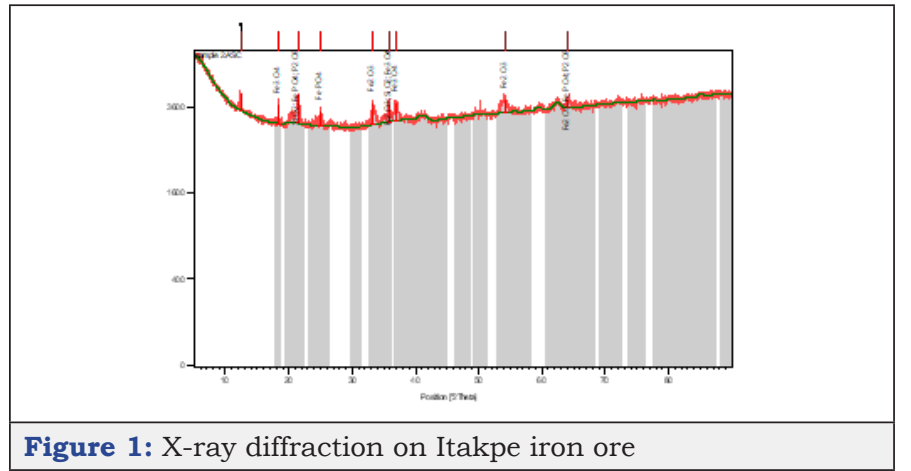

Figure 1: X-ray diffraction on Itakpe iron ore
Figure 1 \& Table 2

Table 2: Identified patterns list: Itakpe iron ore.

\begin{tabular}{|c|c|c|c|c|c|c|}
\hline $\begin{array}{c}\text { Visi- } \\
\text { ble }\end{array}$ & $\begin{array}{c}\text { Ref. } \\
\text { Code }\end{array}$ & Score & $\begin{array}{c}\text { Compo- } \\
\text { und } \\
\text { Name }\end{array}$ & $\begin{array}{c}\text { Displace- } \\
\text { ment } \\
{\left[{ }^{\circ} 2 \mathrm{Th} .\right]}\end{array}$ & $\begin{array}{c}\text { Scale } \\
\text { Factor }\end{array}$ & $\begin{array}{c}\text { Chemical } \\
\text { Formula }\end{array}$ \\
\hline$*$ & $85-0599$ & 50 & Hem-atite & 0 & 0.69 & $\mathrm{Fe}_{2} \mathrm{O}_{3}$ \\
\hline$*$ & $76-0931$ & 49 & $\begin{array}{c}\text { Silicon } \\
\text { Oxide }\end{array}$ & 0 & 0.93 & $\mathrm{Si} \mathrm{O}_{2}$ \\
\hline$*$ & $74-1910$ & 31 & $\begin{array}{c}\text { Magn- } \\
\text { etite }\end{array}$ & 0 & 0.41 & $\mathrm{Fe}_{3} \mathrm{O}_{4}$ \\
\hline$*$ & $23-1301$ & 12 & $\begin{array}{c}\text { Iron } \\
\text { Phosp- } \\
\text { hate }\end{array}$ & 0 & 0.15 & $\mathrm{Fe} \mathrm{P} \mathrm{O}_{4}$ \\
\hline & 22 & $\begin{array}{c}\text { Phosp- } \\
\text { Oxide }\end{array}$ & 0 & 0.14 & $\mathrm{P}_{2} \mathrm{O}_{5}$ \\
\hline
\end{tabular}

Source from the XRD Analysis

Metallurgical coking coal: The coking coal used for this experiment was selected from among the imported Metallurgical Coking Coal at the Ajaokuta Steel Company Limited. The chemical compositions of the coking coal was determined by the supplier of the coking coal to the steel plant before importing them to the steel company. The chemical compositions of the coal is shown in the Table 3 below:

Table 3: Chemical analysis of metallurgical coking coal.

\begin{tabular}{|c|c|c|}
\hline S/No & Chemical Compositions & Percentage (\%) \\
\hline 1 & Fixed Carbon & 85 \\
\hline 2 & Volatile Matter & 2.95 \\
\hline 3 & Ash Content & 9.5 \\
\hline 4 & Moisture & 2 \\
\hline 5 & Sulphur & 0.5 \\
\hline 6 & Phosphorus & 0.05 \\
\hline
\end{tabular}

Source: Ajaokuta Steel Company Limited, Ajaokuta

\section{Equipment and methods}

Some important equipment that is relevant to the study of reducibility was used for this research work.

Sample handler: The Itakpe iron ore lumps were carefully packaged to prevent them from breaking.

Muffle furnace: A Muffle furnace was used for the heating of the iron ores lumps to the required temperatures and time. The Muffle Furnace used for this experiment has a model number LABE 1210 , Divine international with heating capacity of $1500^{\circ} \mathrm{C}$.

Inverted metallurgical microscope: This instrument with model name XJL-17 was used for the examination of the microstructures of the iron ore lump samples before and after the reducibility tests.

\section{Methods}

Tables 1 Shows the chemical compositions of the Itakpe Iron ore lumps. The iron ore concentrate has phosphorus in traces The morphologies of the ore was determined using the X-Ray Diffraction methods as shown in Figure 2 with other details in Table 2. 


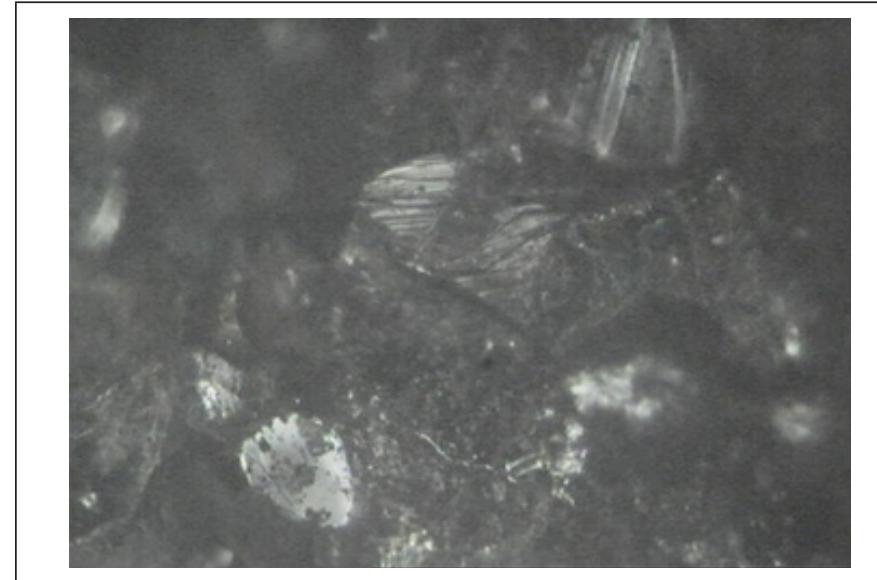

Figure 2: Shows the microscope of the Itakpe iron ore before the reducibility experiment.

Experimental procedure of reducibility: Reducibility is a summary of raw materials properties, which determines the rate of conversion of iron oxides to metals by treatment with reluctant. A measure of reducibility is represented by a weight loss of ore samples per time unit caused by transition of oxygen into gas [3].

\section{Experimental procedure for reduction studies}

A. The Itakpe Iron ore lumps were used for these experiments, while a metallurgical coking coal obtained from the Ajaokuta Steel Company Limited was also used as a reducing agent (reductant).

B. The collected iron ores lumps were crushed to $15-20 \mathrm{~mm}$ sizes

C. The collected metallurgical coking coal was crushed to $-5+15$ size.

D. The chemical compositions of the Metallurgical coking coal is shown in Table 3

E. The crushed iron ore lumps were dried in the laboratory dry oven to eliminate moisture content that was present in the ores as they were subjected to a temperature of $120^{\circ} \mathrm{C}$.

F. The crushed iron ore lumps were taken inside six stainless steel containers (size: $0.6075 \mathrm{~cm}$ height $\times 0.5940 \mathrm{~cm}$ inside diameter) with mouths tightly closed by airtight covers having out let for exit gases. Then the lumps were surrounded with metallurgical coking coal, which serves as reducing agent in the experiments at various period and time.

The prepared samples were placed at the centre of the crushed coking coal. The processes were to ensure that the reducing processes were performed without any hindrance. The muffle furnace was used to heat up the iron ore lumps to the required temperatures of $800{ }^{\circ} \mathrm{C}, 840{ }^{\circ} \mathrm{C}, 880{ }^{\circ} \mathrm{C}, 920{ }^{\circ} \mathrm{C}, 960{ }^{\circ} \mathrm{C}$ and 1000 ${ }^{\circ} \mathrm{C}$, at $8{ }^{\circ} \mathrm{C}$ per minute's rate. The samples got soaked at various temperatures as indicated above by varying the soaking period in the range of 20-120 minutes.

The reducibility tests were performed in accordance at the stipulated temperatures. Each of the containers was properly labelled for the specific experiments. The samples were brought out from the muffle furnace at designated interval of 20 minutes and the same trend were followed for the rest samples at an interval of 40 minutes up to 120 minutes of residence in the furnace. The containers containing the samples were brought out from the muffle furnace and were allowed to cool at the normal atmospheric air. The weight losses analyses of the iron ore lumps, were determined, and recorded. The reducibility of the iron ore lumps were calculated by using the following formula.

\section{Microscope examination}

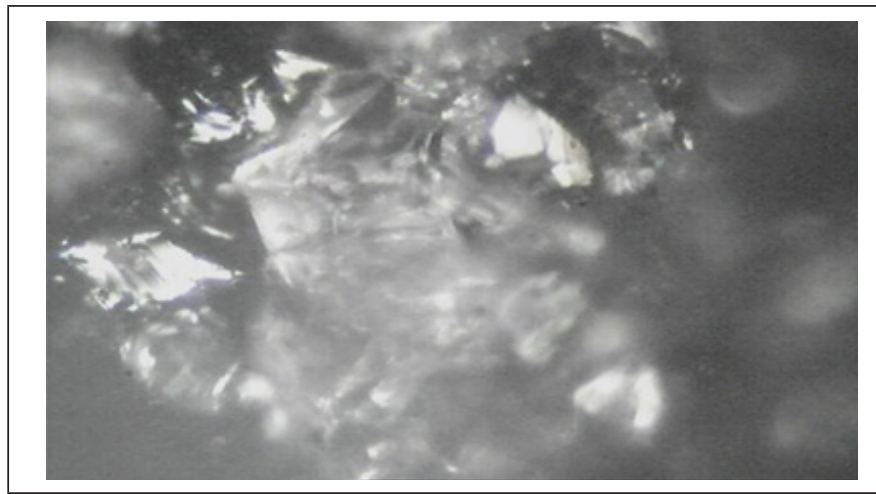

Figure 3: Reduced ore $@ 800{ }^{\circ} \mathrm{C}$ (Partially reduced) after reducibility experiment.

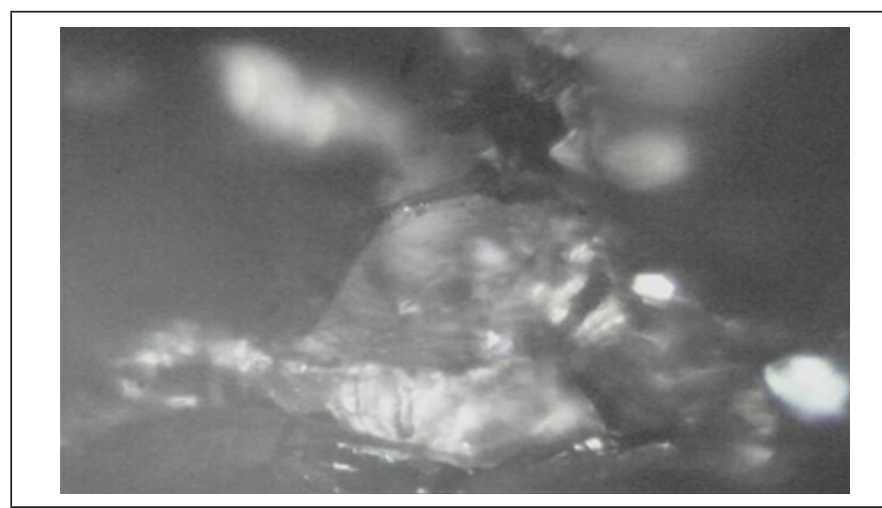

Figure 4: Reduced ore $@ 840{ }^{\circ} \mathrm{C}$ (Partially reduced) after reducibility experiment.

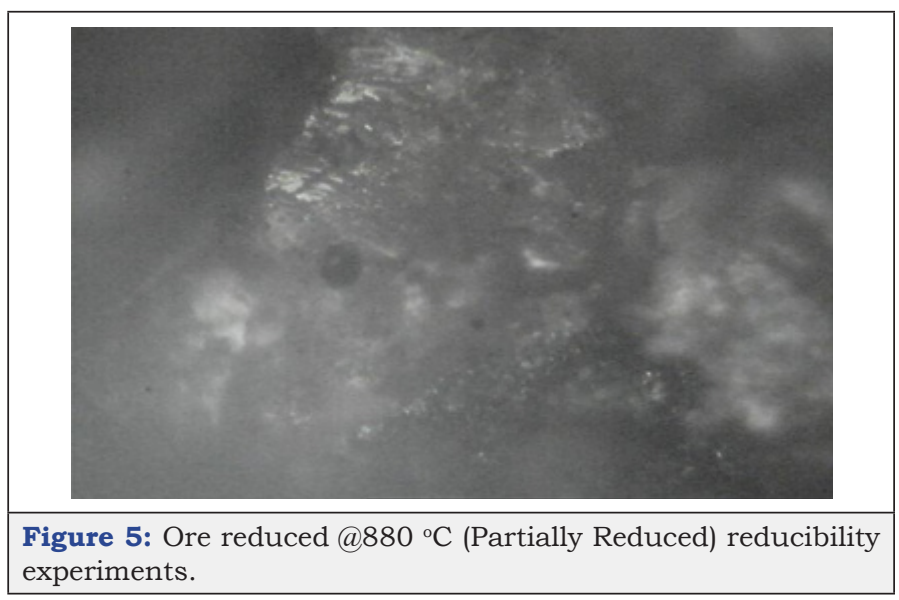

The Inverted Metallurgical Microscope was used to examine the iron ore lumps. Some important distinct phases were identified in the Itakpe iron ore with the use of optical microscopy; the iron 
ore shows some grey like structures, some whitish mottled and blackish / whitish location. These structures and features of the Itakpe iron ore lumps were observed using as inverted Metallurgical Microscope as shown in Figure 2 before the reducibility tests were carried out (Figure 3-8).

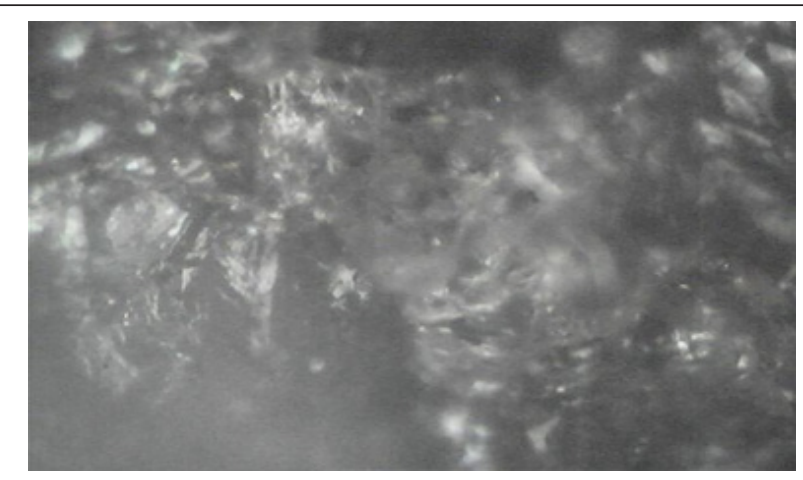

Figure 6: Ore reduced $@ 920^{\circ} \mathrm{C}$ (Partially reduced) after reducibility experiment.

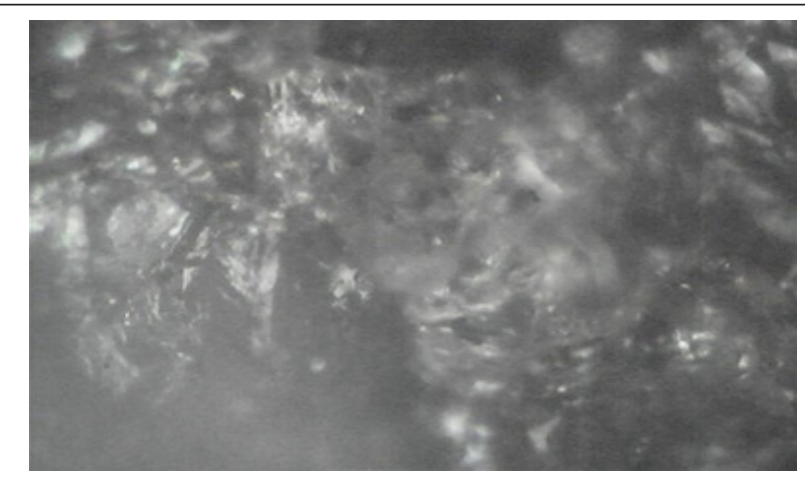

Figure 7: Ore reduced @ $960{ }^{\circ} \mathrm{C}$ (Fully (Reduced) after reducibility experiment.

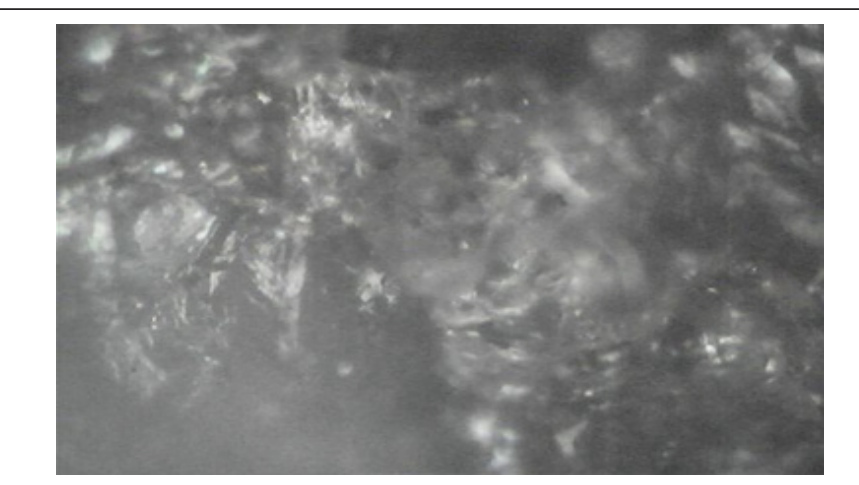

Figure 8: Ore reduced @ $1000{ }^{\circ} \mathrm{C}$ (Fully reduced) after reducibility experiment.

\section{The Thermogravimetric Analysis (TGA) of Itakpe iron} ore

The line with blue colour runs on $30{ }^{\circ} \mathrm{C}$ and moved upwards until it got to the peak value of Deriv weight (\%C) of 0.0048 . This value declined and rose until it achieved a stable value and finally attained a value of 0.0007 at the Drevi weight (\%C). On the other hand, the line with light green colour indicates weight (\%) versus temperature. The weight (\%) started from $100{ }^{\circ} \mathrm{C}$ and continues to decline until it got to $1000{ }^{\circ} \mathrm{C}$ with corresponding value at
99.2. Figure 9 shows the Isothermal behavior of the thermal decomposition of the Itakpe iron ore.

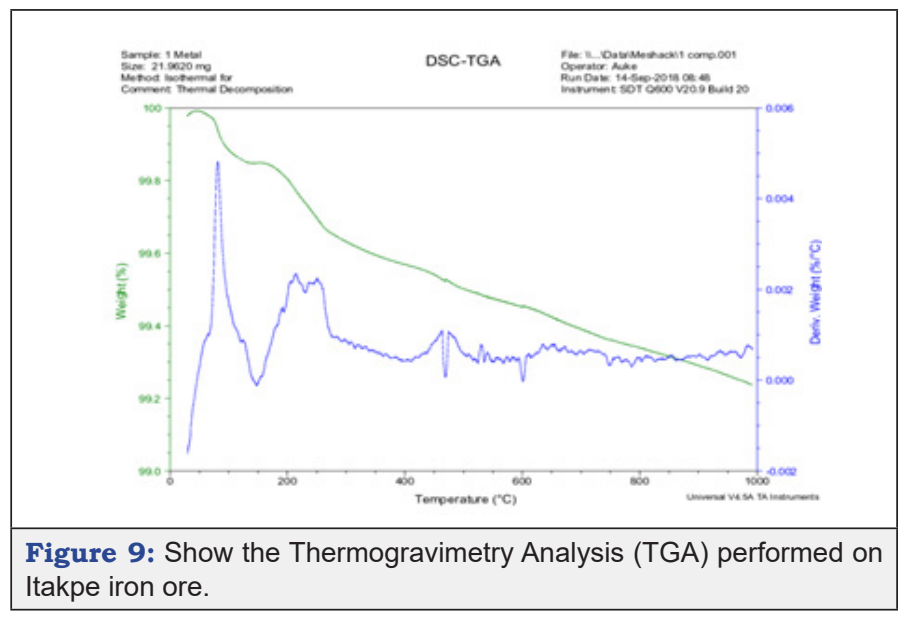

\section{Scanning Electron Microscope (SEM) of Itakpe iron ore}

Examination by Scanning Electron Microscopy (SEM) /EnergyDispersive Spectroscopy (EDS) shows that there are grey phase with quartz, the white phase hematite, and the mottled areas intergrowths of hematite and magnetite (Figure 10).

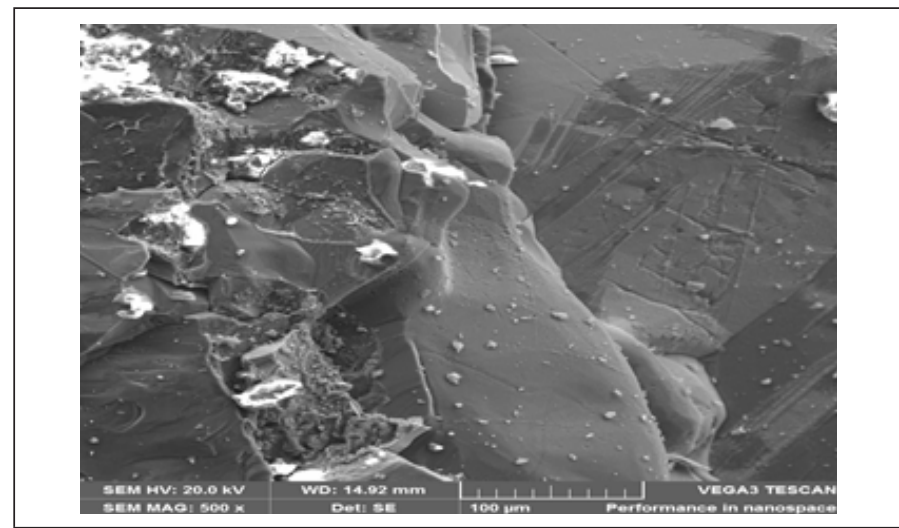

Figure 10: Shows the Scanning Electron Microscopy SEM of the Itakpe Iron ore at $100 \mu \mathrm{m}$.

Electron image of the spectrum location 37,38 and 39 at $10 \mu \mathrm{m}$ Itakpe iron ore: Figure 11 shows the three-spectrum location that was taken in order to determine the concentration of ore. The locations of the spectrum are 5738 and 39 at $10 \mu \mathrm{m}$.

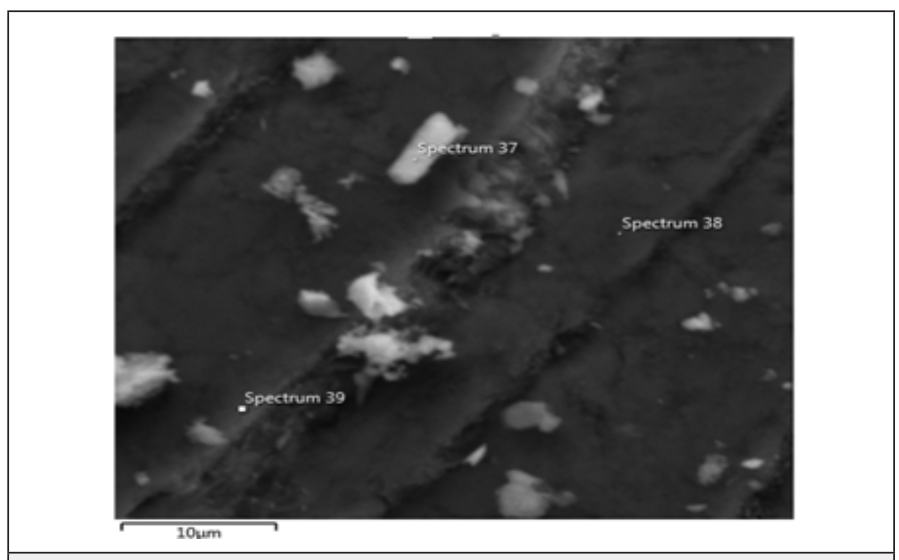

Figure 11: Shows Electron Image of the spectrum locations 37, 38 and 39 at $10 \mu \mathrm{m}$. 
Energy-Dispersive Spectroscopy (EDS) of Itakpe iron ore: Figure 12 shows spectrum 39 where the concentration of the elements are distributed with weight (\%) concentration ranging from $\mathrm{Fe}, \mathrm{O} \mathrm{Al}, \mathrm{Si}$ and $\mathrm{C}$ and with their corresponding density values.

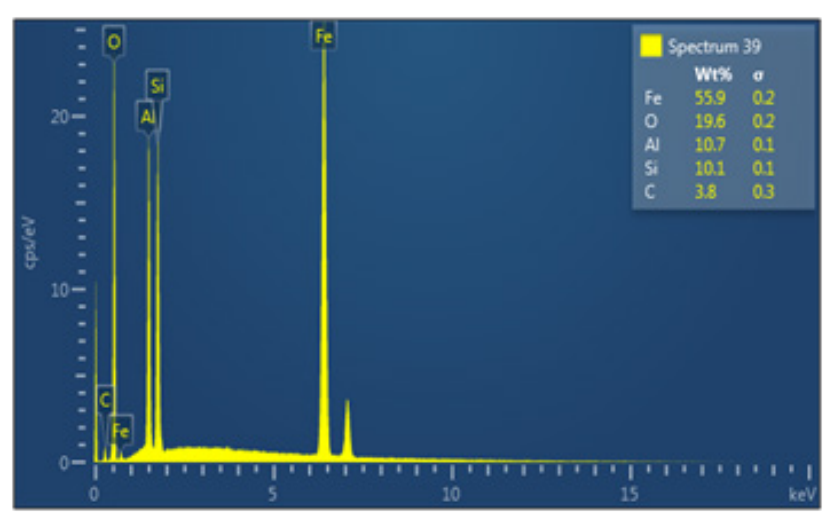

Figure 12: Shows energy dispersive spectroscopy.

\section{Results and Discussion}

\section{Results}

Table 4 \& Figures 13 shows the reducibility as a function of furnace holding time for the reduction of Itakpe iron ore lumps at temperature between $800{ }^{\circ} \mathrm{C}-1000{ }^{\circ} \mathrm{C}$.

Table 4: Itakpe iron ore lumps.

\begin{tabular}{|c|c|c|}
\hline Temperature & Time (in min) & Reducibility \\
\hline \multirow[t]{6}{*}{$800^{\circ} \mathrm{C}$} & 20 & 54.8 \\
\hline & 40 & 55.2 \\
\hline & 60 & 57.7 \\
\hline & 80 & 59.2 \\
\hline & 100 & 59.8 \\
\hline & 120 & 68.1 \\
\hline Temperature & Time (in min) & Reducibility \\
\hline \multirow[t]{6}{*}{$840^{\circ} \mathrm{C}$} & 20 & 56.1 \\
\hline & 40 & 57.1 \\
\hline & 60 & 59.5 \\
\hline & 80 & 60.7 \\
\hline & 100 & 61.3 \\
\hline & 120 & 69.7 \\
\hline Temperature & Time (in min) & Reducibility \\
\hline \multirow[t]{6}{*}{$880^{\circ} \mathrm{C}$} & 20 & 60.1 \\
\hline & 40 & 61.7 \\
\hline & 60 & 62.6 \\
\hline & 80 & 63.9 \\
\hline & 100 & 64.3 \\
\hline & 120 & 70.7 \\
\hline Temperature & Time in min) & Reducibility \\
\hline \multirow[t]{4}{*}{$920^{\circ} \mathrm{C}$} & 20 & 62.2 \\
\hline & 40 & 63.9 \\
\hline & 60 & 64.1 \\
\hline & 80 & 65.6 \\
\hline
\end{tabular}

\begin{tabular}{|c|c|c|}
\hline & 100 & 68.1 \\
\hline & 120 & 72 \\
\hline Temperature & Time( in min) & Reducibility \\
\hline $960^{\circ} \mathrm{C}$ & 20 & 63.3 \\
\hline & 40 & 64.2 \\
\hline & 60 & 66.5 \\
\hline & 80 & 68.5 \\
\hline Temperature & 100 & 71.4 \\
\hline $1000^{\circ} \mathrm{C}$ & 120 & 73 \\
\hline & Time (in min) & Reducibility \\
\hline & 20 & 64.9 \\
\hline & 40 & 65.3 \\
\hline & 60 & 67.4 \\
\hline & 80 & 69.7 \\
\hline & 100 & 72.9 \\
\hline & 120 & 74.3 \\
\hline
\end{tabular}

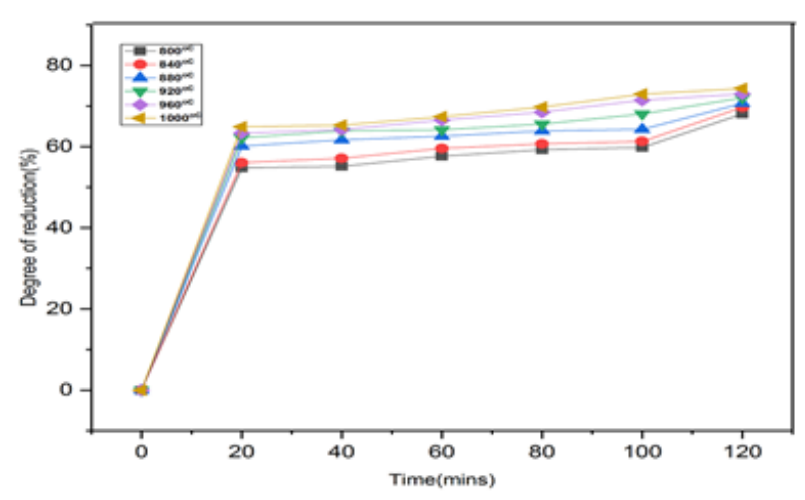

Figure 13: Degree of reduction (\%) of Itakpe iron ore lumps Versus Time (in mins) at temperature between $800^{\circ} \mathrm{C}$ to $1000^{\circ} \mathrm{C}$.

\section{Discussion}

The study of the reducibility on the Itakpe iron ore lumps:

A. Reducibility iron ore lumps

The samples were heated up to various temperatures ranging from $800{ }^{\circ} \mathrm{C}-1000{ }^{\circ} \mathrm{C}$ and the samples were allowed to soak for a period of time ranging from 20 minutes to 120 minutes. The corresponding values collected were recorded and these obtained values were used to plot graphs as a function of furnace holding time for the reduction of the ore at a temperature between $800{ }^{\circ} \mathrm{C}$ $1000^{\circ} \mathrm{C}$.

The ores cracked into fine fragments during reduction at 960 ${ }^{\circ} \mathrm{C}$ for 80 minutes to $1000{ }^{\circ} \mathrm{C}$ for 120 minutes. These results could be found from Figure 14-25. Figure 19 shows that the ore lumps reduced @960 ${ }^{\circ} \mathrm{C}$ for 120 minutes with significant fragmentations and Figure 25 showed that the Itakpe iron ore reduced @ $1000{ }^{\circ} \mathrm{C}$ for 120 minutes total fragmentation of fine iron ore lump particles .

The analyses on the ores are attributed to the higher rate of $\mathrm{Fe}_{2} \mathrm{O}_{3}-\mathrm{Fe}_{3} \mathrm{O}_{4}$ transformation and generation of higher thermal strain. An increased degree of $\mathrm{Fe}_{2} \mathrm{O}_{3}-\mathrm{Fe}_{3} \mathrm{O}_{4}$ transformation increases the volumetric strain and thus the cracking tendency. 


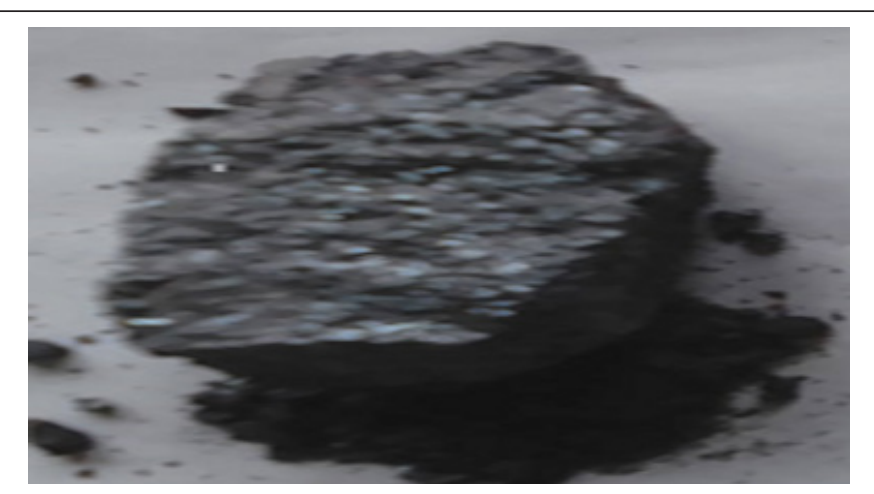

Figure 14: Shows the reduced Ore @ $960{ }^{\circ} \mathrm{C}$ for $20 \mathrm{mins}$.

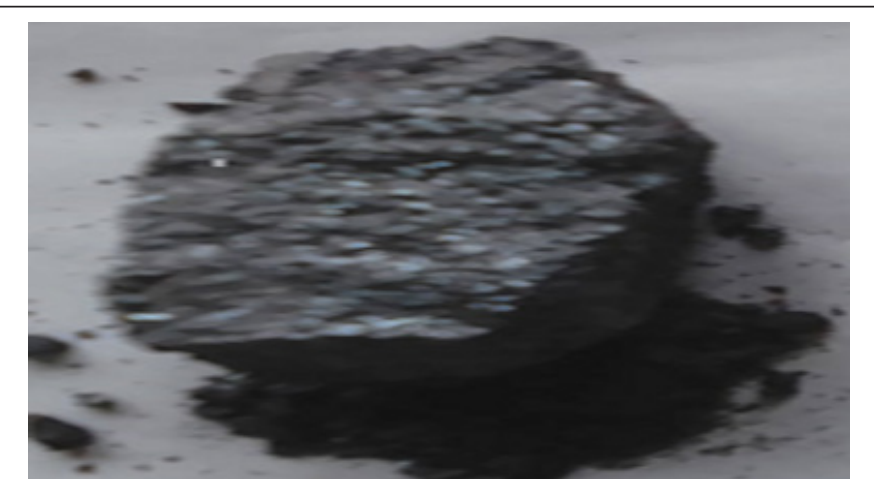

Figure 15: Shows the reduced Ore @ 960 $\mathrm{C}$ for $40 \mathrm{mins}$.

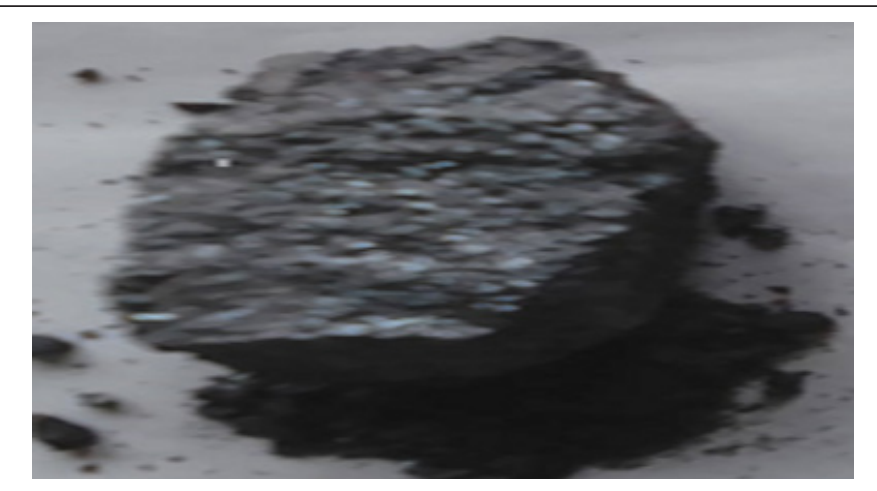

Figure 16: Shows the reduced Ore@960 다 for $60 \mathrm{mins}$.

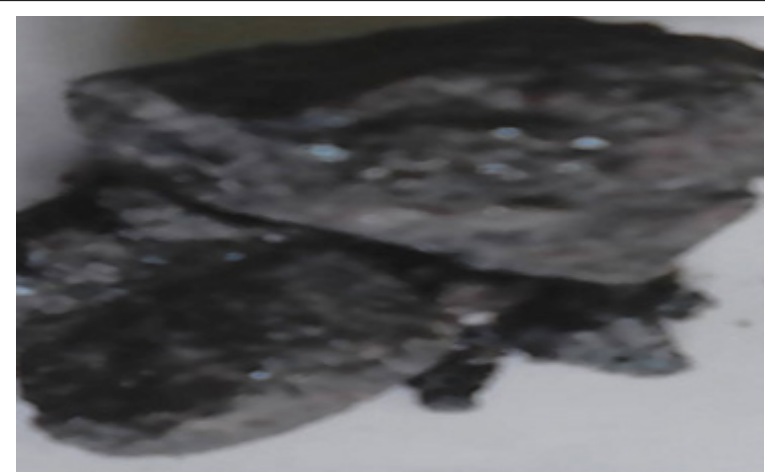

Figure 17: Shows the reduced Ore @ $960{ }^{\circ} \mathrm{C}$ for $80 \mathrm{mins}$.

B. Effect of time on degree of reduction

The research work carried out indicated that the rapid heating of the ore lumps have significant effects on the heating time. The reduction of the ore behaviour showed some significant effects on the reducibility tests. It was discovered that all the reduced lumps reduced completely within 120 minutes. The excessively high reducibility in the first 40 minutes was generally because of the release of volatiles from coal used as a result of their reformation into $\mathrm{H}_{2}$, $\mathrm{CO}$, etc.

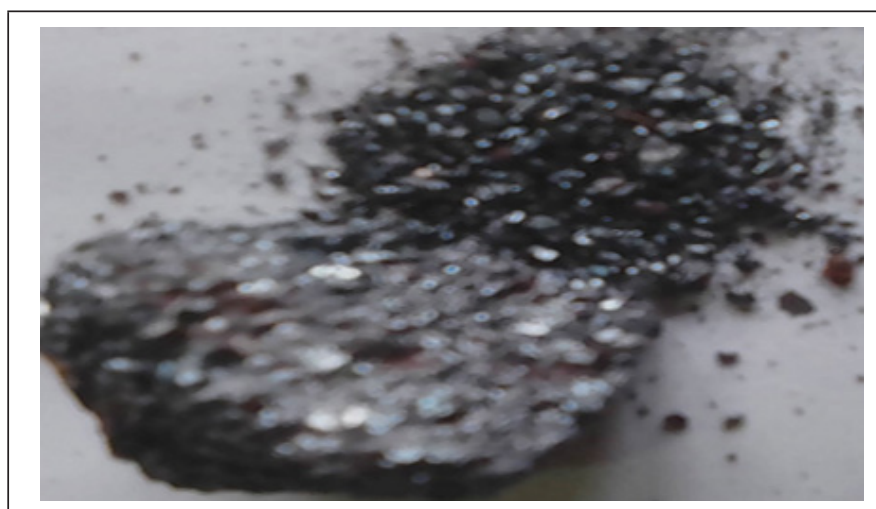

Figure 18: Shows the reduced Ore@ $960^{\circ} \mathrm{C}$ for 100mins.

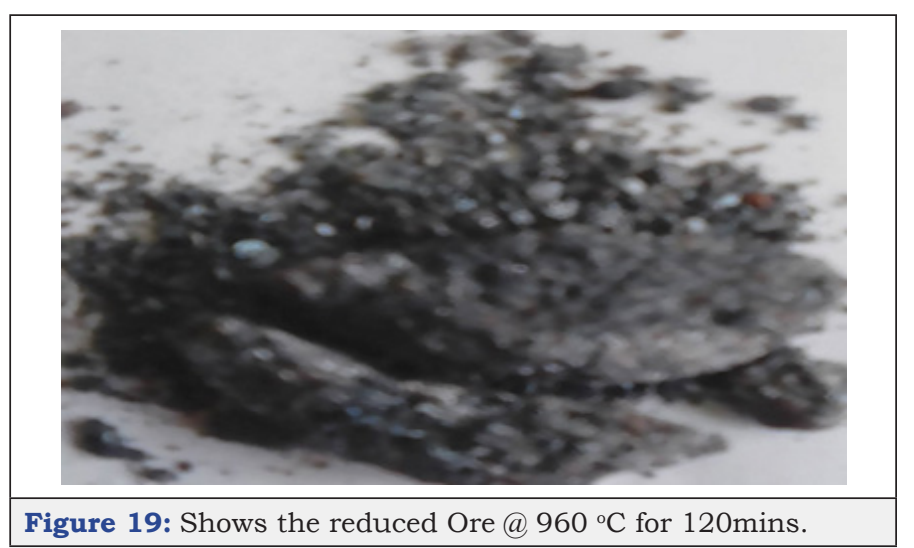

Figure 19: Shows the reduced Ore @ $960{ }^{\circ} \mathrm{C}$ for 120 mins.

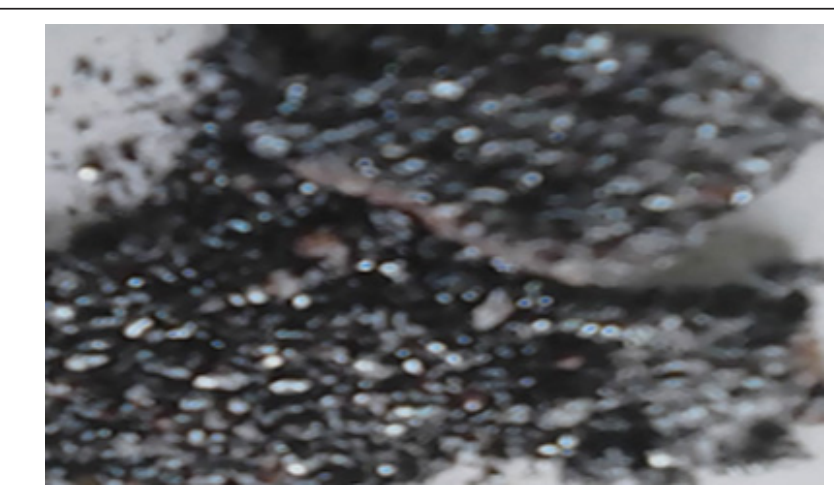

Figure 20: Shows the reduced ore @ $1000{ }^{\circ} \mathrm{C}$ for $20 \mathrm{mins}$.

The major participation of these reducing gases in the reduction of iron oxide (i.e. an appreciable presence of $\mathrm{H}_{2}$ and $\mathrm{CO}$ in the reduction chamber gives a boost in the reduction rate). The decrease in reduction rate with increasing time above 60 minutes was because of the combined effects of an increase in product metallic layer thickness and diminished evolution of volatile matter from the coal. An increase in the thickness of iron layer products offer greater resistance in the diffusion of carbon and reducing gas to the surface of unreduced iron oxide. 
C. Effect of heating mode on the reducibility tests

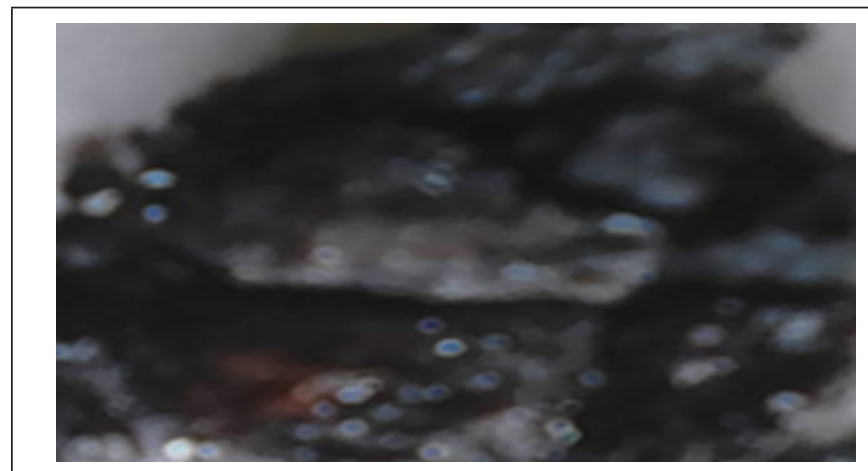

Figure 21: Shows the reduced ore @ $1000{ }^{\circ} \mathrm{C}$ for $40 \mathrm{mins}$.

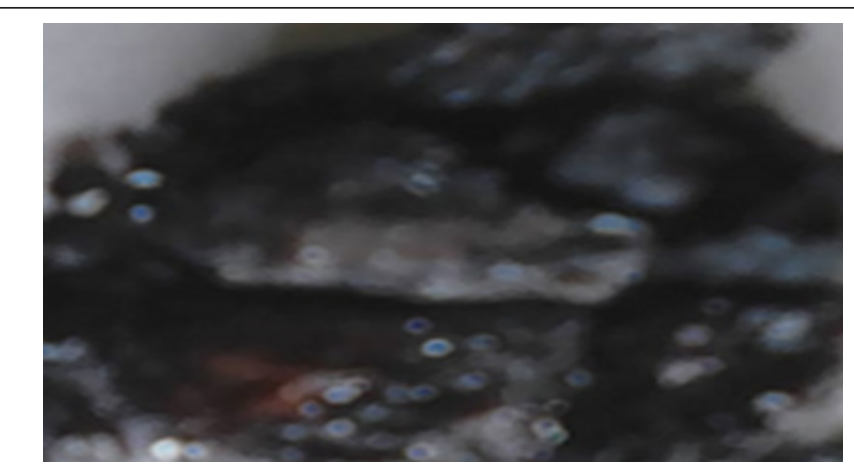

Figure 21: Shows the reduced ore @ $1000{ }^{\circ} \mathrm{C}$ for $40 \mathrm{mins}$.

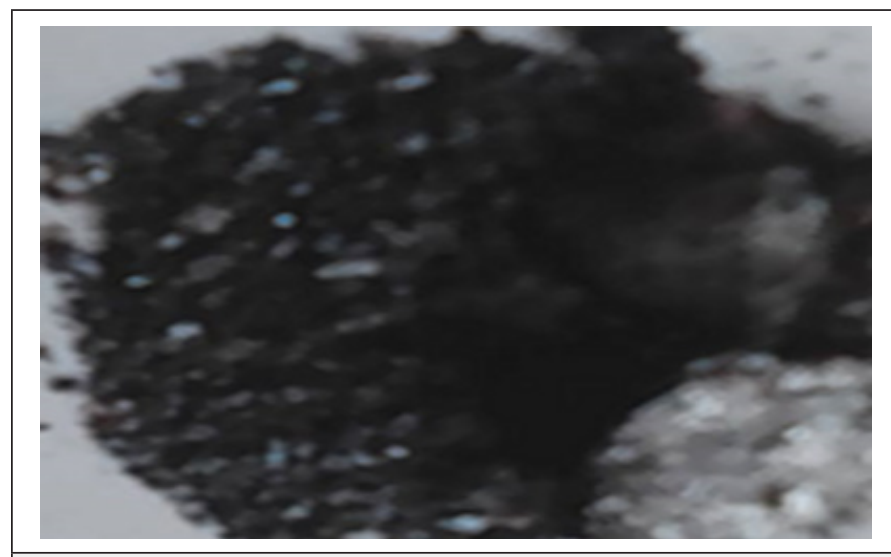

Figure 22: Shows the reduced ore @ $1000{ }^{\circ} \mathrm{C}$ for $60 \mathrm{mins}$.

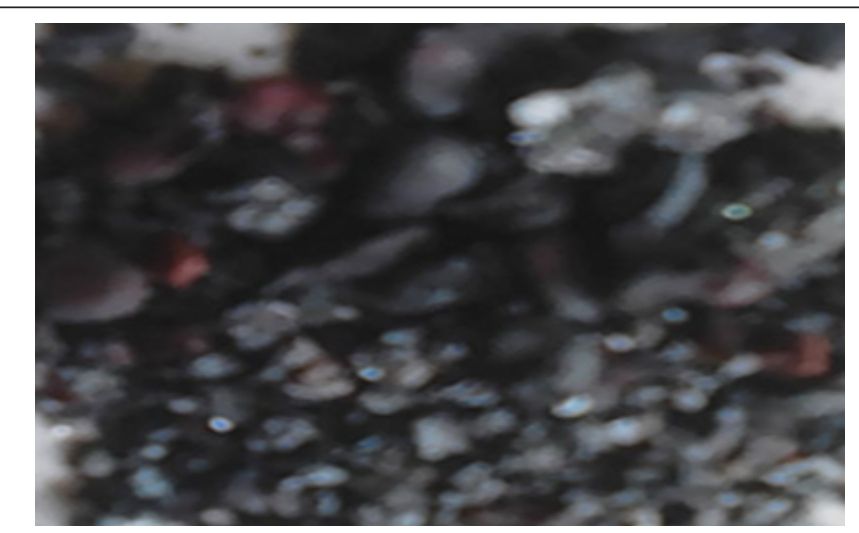

Figure 23: Shows the reduced ore @ $1000^{\circ} \mathrm{C}$ for 60 mins.

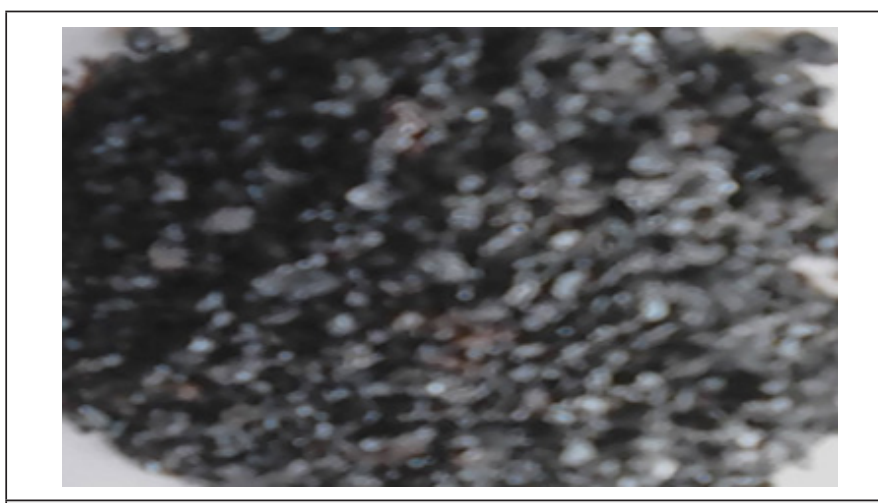

Figure 24: Shows the reduced Ore @ $1000{ }^{\circ} \mathrm{C}$ for $100 \mathrm{mins}$.

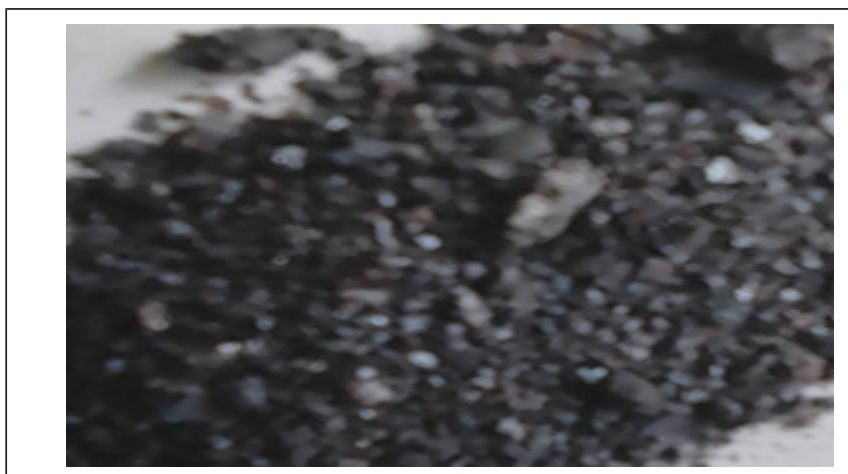

Figure 25: Shows the reduced Ore @ $1000{ }^{\circ} \mathrm{C}$ for $120 \mathrm{mins}$.

The effect of heating mode on the samples was studied with a view to determine its effects on the reducibility of the ores. The ore were reduced by using coking coal at temperature range between $800{ }^{\circ} \mathrm{C}-1000{ }^{\circ} \mathrm{C}$ (the soaking times were varied from 20 minutes -120 minutes at an interval of 20 minutes). These experiments were performed under rapid and slow heating conditions.

It was noted that rapid heating have slowing heating effects on reduction temperature which gives appreciably higher degree of reduction. It was more likely that rapid heating from $920{ }^{\circ} \mathrm{C}$ to $1000{ }^{\circ} \mathrm{C}$ causes higher rate of volatile matter escaping from the metallurgical coking coal, thereby providing less time for $\mathrm{H} 2$ and CO (reducing gases) on the ores. The results indicate that there were higher rate of reducibility during the rapid heating ore at lower heating operation. Volatile matters released from the coal were done at a slower rate.

D. Scanning Electron Microscopy (SEM) of ore (reduced ore at $800{ }^{\circ} \mathrm{C}, 920^{\circ} \mathrm{C}$ and $1000{ }^{\circ} \mathrm{C}$ )

The ore @ $900{ }^{\circ} \mathrm{C}$ for 120 minutes, $920^{\circ} \mathrm{C}$ for 120 minutes and $1000^{\circ} \mathrm{C}$ for 120 minutes after the reducibility tests were performed : SEM examinations show the morphology of the sample at $100 \mu \mathrm{m}$ (Figure 26-28).

E. Energy-Dispersive Spectroscopy (EDS) of ore after the reducibility tests on samples at $800^{\circ} \mathrm{C}, 920^{\circ} \mathrm{C}$ and $1000{ }^{\circ} \mathrm{C}$

Figure $29 \mathrm{a} \& 29 \mathrm{~b}$ show ore at $800{ }^{\circ} \mathrm{C}$ for 120 minutes after the reducibility tests were carried out. The concentrations of the elements are distributed in weight (\%) concentration ranging from $\mathrm{O}, \mathrm{Fe}, \mathrm{C}, \mathrm{Al}, \mathrm{Si}$ and $\mathrm{P}$ and with their corresponding density values. 

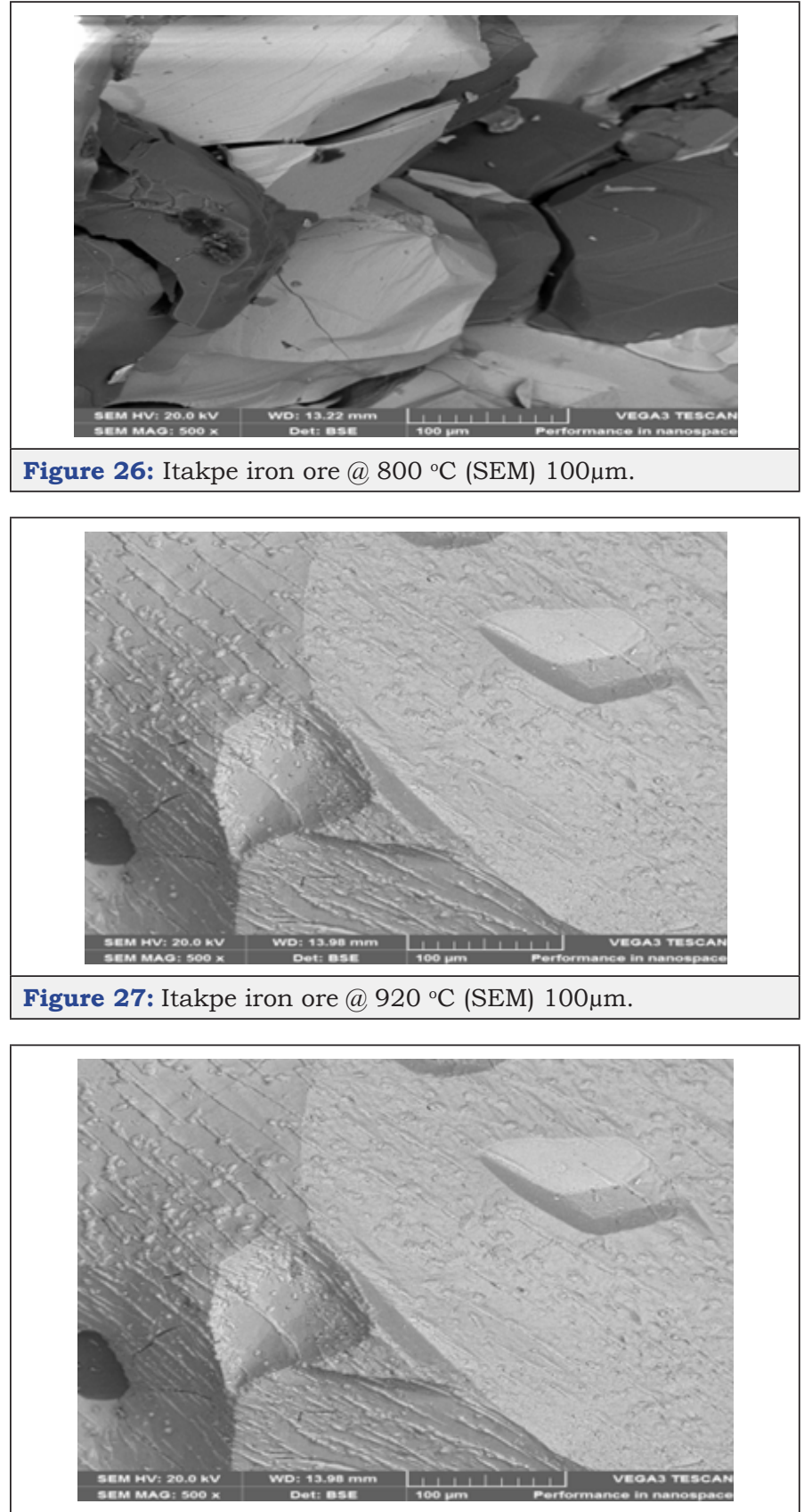

Figure 28: Itakpe iron ore @ $1000{ }^{\circ} \mathrm{C}(\mathrm{SEM}) 100 \mu \mathrm{m}$.

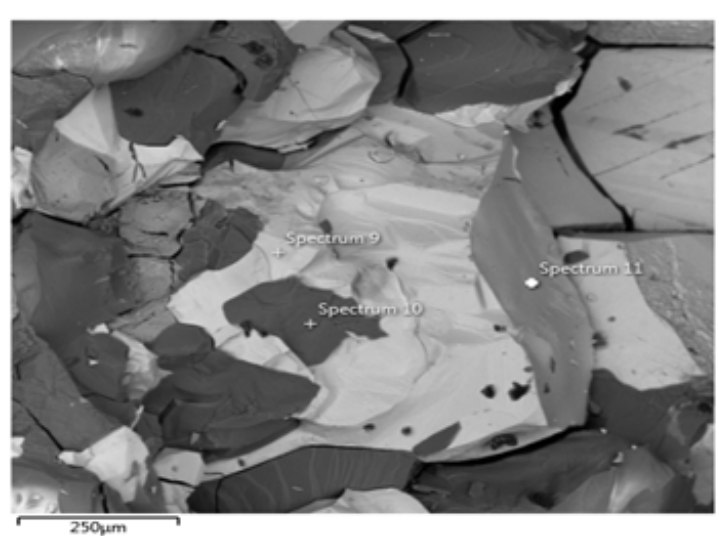

Figure 29a: Shows electron image 4 of the Itakpe Iron Ore @ $800{ }^{\circ} \mathrm{C}$ after reducibility test.

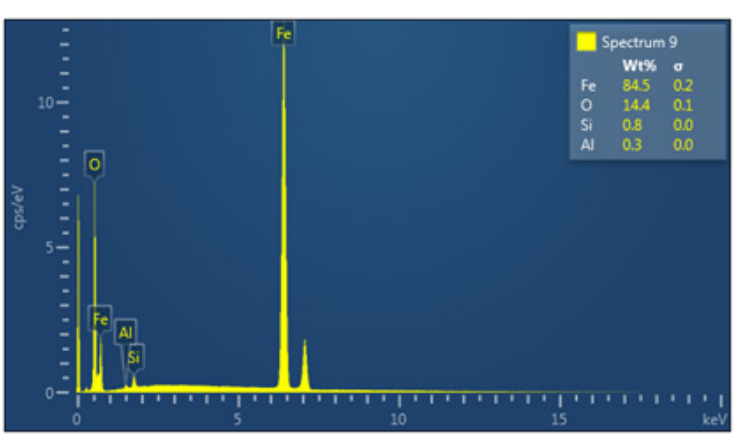

Figure 29b: Shows the EDS of Itakpe iron Ore @ $800{ }^{\circ} \mathrm{C}$ after reducibility test.

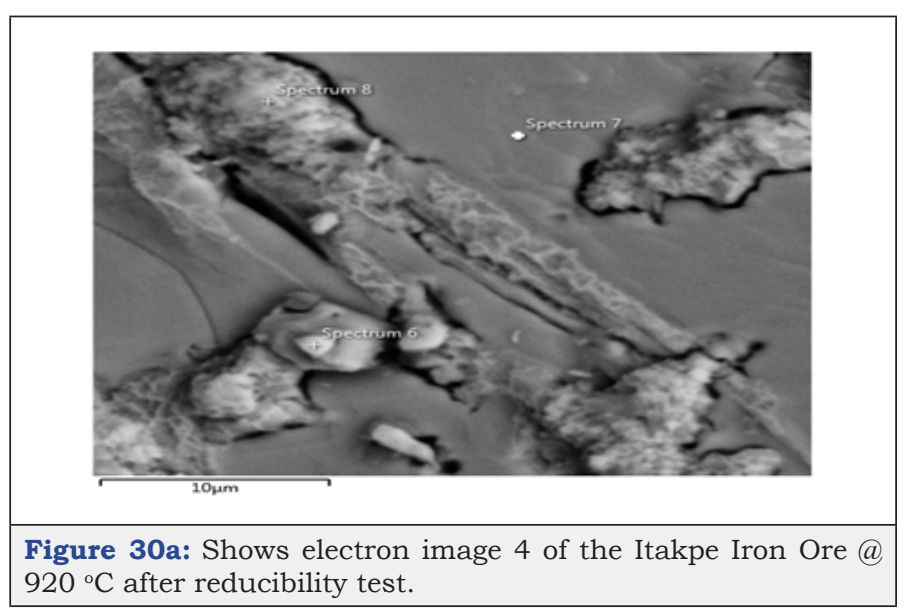
$920{ }^{\circ} \mathrm{C}$ after reducibility test.

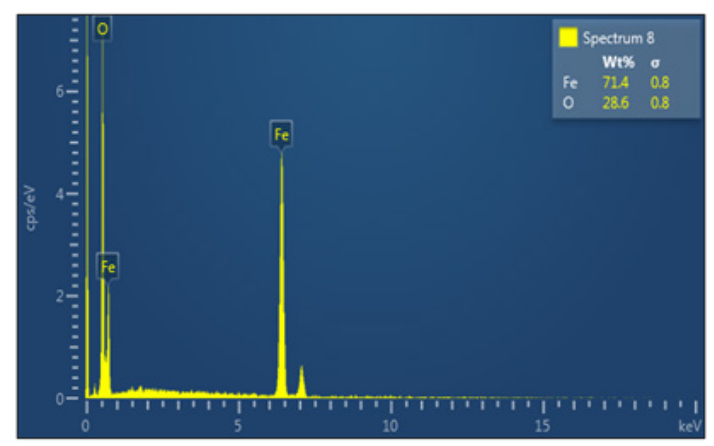

Figure 30b: Shows the EDS of Itakpe iron Ore @ $920^{\circ} \mathrm{C}$ after reducibility test.

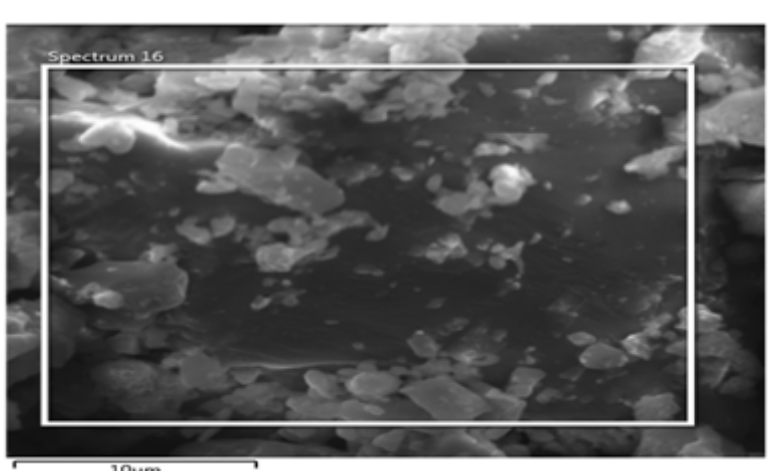

Figure 31a: Shows electron image 4 of the Itakpe Iron Ore @ $920^{\circ} \mathrm{C}$ after reducibility test. 
Figure $30 \mathrm{a} \& 30 \mathrm{~b}$ show the ore at $920^{\circ} \mathrm{C}$ for 120 minutes after the reducibility test was carried out. The concentration of the elements are distributed with weight (\%) concentration on Fe and 0 with their corresponding density values.

Figure $31 \mathrm{a} \& 31 \mathrm{~b}$ show the ore at $1000{ }^{\circ} \mathrm{C}$ for 120 minutes after the reducibility tests were carried out. The concentration of the elements are distributed with weight (\%) concentration ranging from $\mathrm{Ti}, \mathrm{O}, \mathrm{Fe}, \mathrm{Al}$, and $\mathrm{Si}$ with their corresponding density values.

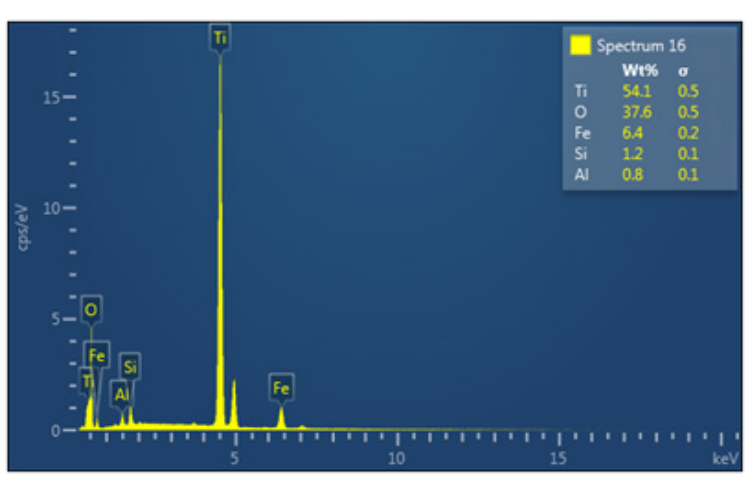

Figure 31b: Shows the EDS of Itakpe iron Ore @ $920{ }^{\circ} \mathrm{C}$ after reducibility test.

\section{Summary of the analysis on results after the reducibility tests (SEM and EDS)}

The results on Table 5 indicates that the ore reduced at $800^{\circ} \mathrm{C}$ for
120 minutes and had a corresponding value of iron (Fe) content of $84.5 \mathrm{wt} \%$, the Fe content reduced from $84.5 \mathrm{wt} \%$ to $71.4 \mathrm{wt} \%$ when the samples were subjected to a heating temperature of $920{ }^{\circ} \mathrm{C}$ for 120 minutes . At $1000{ }^{\circ} \mathrm{C}$ for 120 minutes, the Fe content reduced to $6.4 \mathrm{wt} \%$. The analyses translate to mean ores fully reduced at this temperature and time. This can be further showed that the ores reduced in this order $800{ }^{\circ} \mathrm{C}>920^{\circ} \mathrm{C}>1000{ }^{\circ} \mathrm{C}$. The results obtained were also represented on a graph showed in Figure 32.

\section{Conclusion}

The study of the reducibility ores were intensively carried out. The studies carried out revealed the followings:

(a) The time of reduction: The ores indicate that there was a greater influence on the level of reducibility. It was observed that reducibility increased with increase with time.

(b) The reduced ores are identical in all the studies. The use of the metallurgical coking coal as reducing agent had great effects on the lumps, as there were significant influences on the reducibility on the tested samples.

From the findings of the study, the results and data obtained could be used for further studies. The other ore deposits in the country could also be subjected to some experimental investigations and processes. These processes could be investigated and subjected to the reducibility tests in order to generate the necessary data for future use.

Table 5: analysis of results of samples after performing the reducibility tests using SEM and EDS on Itakpe iron ore.

\begin{tabular}{|c|c|c|c|c|c|c|c|c|c|}
\hline S/NO & $\begin{array}{c}\text { Sample } \\
\text { Name }\end{array}$ & $\begin{array}{c}\text { Temperature in } \\
\text { degree }\end{array}$ & Fe (Wt \%) & $\mathbf{C}(\mathbf{W t} \%)$ & Ca (Wt\%) & 02 (Wt\%) & Al (Wt\%) & Zn (Wt\%) & Si (Wt\%) \\
\hline 1 & Ore Lumps & $800^{\circ} \mathrm{C}$ & 84.5 & 0 & 0 & 14.4 & 0.3 & 0 & 0.8 \\
\hline 2 & Ore Lumps & $920^{\circ} \mathrm{C}$ & 71.4 & 0 & 0 & 28.6 & 0 & 0 & 0 \\
\hline 3 & Ore Lumps & $1000^{\circ} \mathrm{C}$ & 6.4 & 0 & 0 & 37.6 & 0.8 & 0 & 1.2 \\
\hline
\end{tabular}

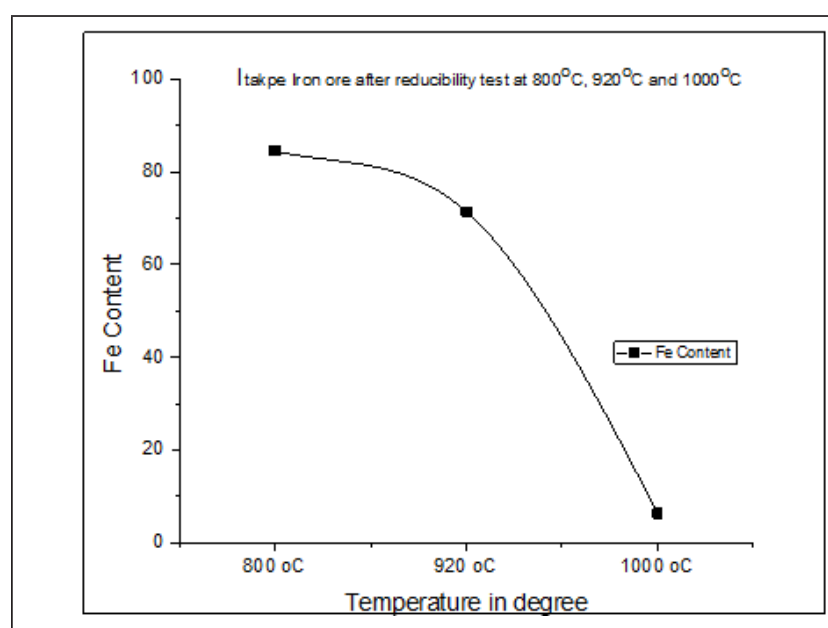

Figure 32: Shows the $\mathrm{Fe}$ content of Itakpe iron ore after the reducibility test $@ 800{ }^{\circ} \mathrm{C}, 920{ }^{\circ} \mathrm{C}$ and $1000{ }^{\circ} \mathrm{C}$ using SEM and EDS.

\section{Recommendations for Future Research}

(a) A lot of resources is needed to perform this type of research work due to its capital involvement. In respect to this, some of the Research Institutions, Universities and Industries could provide enabling environment for students and researchers perform their investigations / studies. In some cases waivers should be granted and sometime cost should be reduced.

(b) It was discovered that ample time is required to complete this type of research work.

(c) Raw materials sourcing is also a very high challenge and the cost of obtaining them is sometimes very outrageous.

(d) The accessibility to source for the raw materials was very difficult as a lot of money will be required to obtain them. The security network of the ore locations and the terrain are not easily accessible. Efforts should therefore be made by all the stake holders to always assist researchers, students and other individuals by creating enabling opportunities for them to have access to these raw materials.

(e) As regards the equipment used in these experiments, some of them were not readily available in Nigeria: such as SEM with EDS, TA, and DTA), XRF, XRD and other facilities. These issues posed lots of difficult as the samples had to be sent to South Africa. 
(f) The collection of the test results are dependent on when the results were ready as this in most case takes a long time coupled with the cost of performing such tests. Even when the equipment's are available in Nigeria, they are in most cases bedeviled with issues ranging from faulty parts, total breakdown, in accuracy, doubts results and non compliance with international standard or global best practices.

(g) The cost of performing such experiments are relatively too high for an average students/ researchers to afford, therefore, Governments and other Research Institutions, Universities and Industries should assist in supporting the researcher in order to encourage them.

(h) In view of the above therefore, the Universities, Research Institutes in Nigeria should collaborate with agencies like the NLNG, TETFUNDS, PTDF, SHELL PB CHEVRON and AGIP etc. to supply equipment's that will aid and facilitate research work. This with a view to collaborating with students/researchers in order to achieve optimal results. (i) The research work performed on the ore is not exhaustive as more work could be carried out with other iron ores available within Kogi State like the Agbajanoko, Oshokosho, Konto Karfi, BassaNge and Muro and in other States of the Federation Nigeria.

\section{References}

1. Adeleye RA (1964) The occurrence of Oolitic iron ore in the middle Niger basin in geology of Nigeria". In: Kogbe CA (Ed.), Edition Elizabeth press, Lagos, Nigeria, pp. 1-10.

2. Akande JM, Adebimpe RA (2004) Physical and chemical analysis of Itakpe iron ore waste. Nigeria Journal of Engineering Research and Development 3(2): 10-15.

3. Mohammed RA, Dada ET, Hassan SB, Abdulwahab M (2014) Assessment of mechanical properties of pellets produced from Itakpe/Agbaja iron ore blends. A paper published in the Nigerian Metallurgical Proceeding at the $30^{\text {th }}$ Annual Conference and Annual General Meeting of the Nigerian Metallurgical Society at the Raw Materials Research and Development. 